\title{
Partitioning of trace metals between soft tissues and shells of Patella aspera
}

\author{
A. Cravo ${ }^{\text {a,* }}$, M.J. Bebianno ${ }^{\text {a }}$, P. Foster ${ }^{\mathrm{b}}$ \\ ${ }^{a}$ Centre of Marine and Environmental Research (CIMA), F.C.M.A., University of Algarve, Campus de Gambelas, 8000-117 Faro, Portugal \\ ${ }^{\mathrm{b}}$ School of Ocean Sciences, University of Wales, Bangor, Gwynedd LL59 5EY, UK
}

Received 27 February 2003; accepted 27 May 2003

\begin{abstract}
This paper describes the partitioning of iron, manganese, zinc, copper, cadmium, cobalt, nickel and lead between the soft tissues and the shells of the gastropod mollusc Patella aspera. Specimens of the limpet P. aspera were collected from a clean coastal marine site (CMS) and from an estuarine contaminated site (ECS) on the south coast of Portugal. Fe and Zn concentrations were significantly lower on both populations and less variable in the shells than in the soft tissues. In contrast Mn concentrations were higher in the shells than in the soft tissues at ECS. The partitioning factor (PF), defined as the ratio between the mean metal concentrations in soft tissues and in the shells, was maximum for iron and minimum for manganese. Between the soft tissues and the shells, only manganese at ECS recorded a significant relationship between metal concentrations, suggesting that the mechanism that controls the accumulation of this essential metal in both tissues was different from the others. From the obtained data, in biomonitoring sewage contamination studies, shells of $P$. aspera can be considered as a good indicator for Mn while the soft tissues for $\mathrm{Zn}$. As copper, cadmium, nickel and cobalt concentrations were much higher in the soft tissues than in the shells $\left(<0.1 \mu \mathrm{g} \mathrm{g}^{-1}\right)$, this indicates that the shells were not a good indicator for these metals because they do not reflect the environmental bioavailability as do the soft tissues.
\end{abstract}

(C) 2003 Elsevier Ltd. All rights reserved.

Keywords: Partitioning; Patella aspera; Soft tissues; Shells; Trace metals

\section{Introduction}

The usefulness of molluscs as sentinel organisms in metal biomonitoring studies is widely recognized (Rainbow, 1990, 1992, 1993, 1997; Rainbow and Phillips, 1993; Langston and Spence, 1995; Brown and Depledge, 1998). Although metals in the soft tissues of marine mollusc has been studied intensively there are only a few data available concerning metals in the shells (Carriker et al., 1980, 1991; Brix and Lyngby, 1985; Bourgoin, 1990; Lingard et al., 1992; Foster and Chacko, 1995; Watson et al., 1995; Prakash et al., 1996; Foster et al., 1997; Price and Pearce, 1997; Giusti et al., 1999; Richardson et al., 2001). Most of these works have been directed either to the soft tissues or to the shells but very few have concurrently addressed trace metal concentrations in both tissues. It is generally recog-

\footnotetext{
* Corresponding author. Tel.: +351-289-800900x7369; fax: +351-289818353.

E-mail address: acravo@ualg.pt (A. Cravo).
}

nized that the soft tissues accumulate higher metal concentrations than the shells (Langston et al., 1998). However, sometimes, mollusc shells accumulate higher concentrations than the soft tissues (Szefer and Szefer, 1985, 1990; ElNady, 1996; Puente et al., 1996; Fishelson et al., 1999; Giusti et al., 1999; de Wolf et al., 2001; Szefer et al., 2002). Shells have important practical advantages over the use of the soft tissues to monitoring metal contamination of the aquatic environment since they show less variability (Bourgoin, 1990; Lingard et al., 1992), integrate elemental concentrations over the life of the animal, preserve the metals after the death of the organisms giving information about the concentrations that they were exposed in the past (Ferrell et al., 1973; Sturesson, 1978; Carriker et al., 1980; Carell et al., 1987) and offer considerable advantages in preservation and storage.

Generally, metal concentrations in the soft tissues show greater variability than in shells usually due to seasonal weight changes (associated with physiological conditions, reproductive state) and consequently, shells may provide a 
more realistic indication of the degree of contamination/ pollution. Due to this fact some authors when considering the metal concentrations in the soft tissues of marine molluscs, to avoid seasonal variations, prefer to correlate them with shell weight, using metal/shell weight indices (Soto et al., 1995, 1997).

Consequently, it is not definitively established which tissue can be used as the best bioindicator in monitoring programmes of metallic contamination/pollution. Of those works addressing metal accumulation in both the soft tissues and shells the majority are about Mytilus spp. but there are also several studies on clams, oysters and other bivalves from marine or estuarine environments (Brix and Lyngby, 1985; Bourgoin, 1990; Szefer and Szefer, 1990; Babukutty and Chacko, 1992; Prakash et al., 1994; El-Nady, 1996; Puente et al., 1996; Szefer et al., 1997, 2002; Fishelson et al., 1999; Giusti et al., 1999). In molluses other than bivalves, namely gastropods, works carried out in polluted areas are sparse. Those were relative to the marine gastropod, Austrocochlea constricta from an area with a commercial shipping harbour and from a marine lake with high levels of recreational activities in the Newcastle region of New South Wales, Australia (Walsh et al., 1994, 1995, respectively), and to the periwinkles Littorina littorea along a pollution gradient in the Scheldt Estuary (de Wolf et al., 2000) and Littorina sabra from the mangrove area along Dar es Salaam, Tanzania (de Wolf et al., 2001).
The objective of this work was to contribute to the knowledge of the partitioning of iron, manganese, zinc, copper, cadmium, cobalt, nickel and lead concentrations between the soft tissues and shells within the available size of the gastropod Patella aspera taken from a clean, coastal marine site and from a contrasting site, an estuarine contaminated environment, relating it to environmental metal bioavailability and to establish the potential of both tissues to be considered a good indicator for metal contamination.

\section{Materials and methods}

\subsection{Sampling and sampling sites}

Twenty-five limpets, $P$. aspera through the available size range $(21-51 \mathrm{~mm})$ were collected from two contrasting sites on the south coast of Portugal in terms of water characteristics and quality. The clean marine site (CMS) is located at $37^{\circ} 20^{\prime} 22 \mathrm{~N}, 8^{\circ} 51^{\prime} 15 \mathrm{~W}$ (Fig. 1), a remote and rugged coastal site on the southwest coast of Portugal with almost invariant salinity regime (range 36.0-36.4) and a mean annual temperature of $18{ }^{\circ} \mathrm{C}$ (Almeida, 1999) where the water chemistry is typical of Atlantic waters, not directly induced by anthropogenic perturbation. The estuarine contaminated site (ECS) is located at $37^{\circ} 4^{\prime} 20 \mathrm{~N}, 8^{\circ} 7^{\prime} 27 \mathrm{~W}$, on

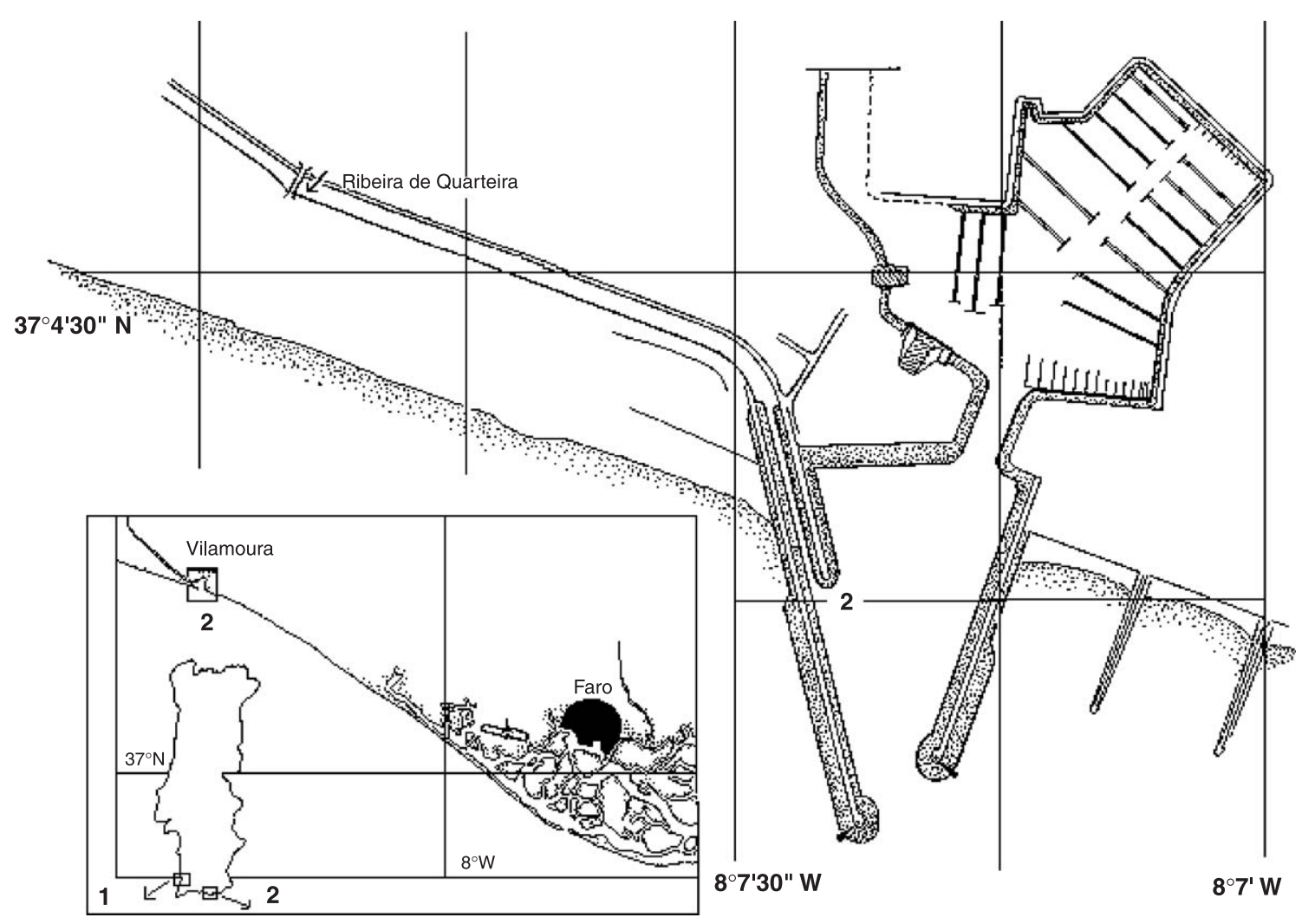

Fig. 1. Location of the sampling sites. 1-CMS, 2-ECS. 
the south coast of Portugal, within the confluence zone of the waters from a small river (Ribeira de Quarteira, receiving sewage discharges) and a marina (Fig. 1). In both sites, $P$. aspera limpets were taken over a longitudinal distance of $10 \mathrm{~m}$.

Data on the quality of the intertidal regime at the ECS have been published elsewhere (Cravo, 1996). At low water, the mean annual water temperature $\left(19.2{ }^{\circ} \mathrm{C}\right)$ was higher than at the CMS whereas the mean salinity (15.4) was much lower. This estuarine location showed a low but highly variable salinity regime (ranging from 7.9 to 23.3 ) and water quality was seriously impaired by the discharge of domestic effluents from a sewage treatment plant (secondary, biological treatment) that serves a population of $\approx 15,000$ inhabitants. Particularly during summer, due to an increase of tourism, the population usually exceed 150,000 inhabitants. Very high concentrations of ammonium $(\approx 300 \mu \mathrm{M})$, phosphate $(\approx 50 \mu \mathrm{M})$, suspended solids $\left(\geq 80 \mathrm{mg} \mathrm{l}^{-1}\right)$ as well as extremely low percentage of dissolved oxygen $\left(<1 \mathrm{mg}^{-1}\right)$ are not unusual (Cravo, 1996).

\subsection{Metal analysis}

All specimens were depurated for $48 \mathrm{~h}$ to eliminate gut contents and the shells were cleaned by scrubbing in distilled deionised water with a toothbrush to remove loosely attached biogenic and inorganic particles and dried at $80{ }^{\circ} \mathrm{C}$ to constant weight. The maximum length of each shell was measured. The soft tissues were separated from the shells with a plastic knife and dried at $80{ }^{\circ} \mathrm{C}$ until constant weight. After drying, the whole soft tissue of each limpet was digested with concentrated $\mathrm{HNO}_{3}$ as described by Bryan et al. (1985). The residue was dissolved in 10\% $\mathrm{HCl}$. Fe, $\mathrm{Mn}, \mathrm{Zn}, \mathrm{Cu}, \mathrm{Cd}, \mathrm{Ni}, \mathrm{Co}$ and $\mathrm{Pb}$ concentrations were determined by flame atomic absorption spectrophotometry. Prior to elemental metal analysis each shell was individually subjected to a further cleaning process designed to remove material that were not an integral component of the crystalline shell matrix (Foster and Chacko, 1995). Each shell was individually treated with $50 \% \mathrm{w} / \mathrm{v}$ hydrogen peroxide in the ratio of $1 \mathrm{ml} \mathrm{g}^{-1}$ shell weight and gently heated at $60{ }^{\circ} \mathrm{C}$ overnight. After rinsing with distilled water, individual shells were placed in vials of appropriate diameter to ensure that the entire surface of the shell was covered with $0.05 \mathrm{M} \mathrm{HCl}$, that was added in the ratio of $1 \mathrm{ml} \mathrm{g}^{-1}$ shell weight and left overnight. After washing and drying, each shell was individually pulverised in an agate mortar and the resulting homogeneous fine powders stored for subsequent analysis.

Duplicate samples of each shell $(0.1 \mathrm{~g})$ were totally digested in a mixture of concentrated nitric acid and $50 \%$ $\mathrm{w} / \mathrm{v}$ hydrogen peroxide. After evaporation to dryness, the residue was redissolved in $2 \mathrm{ml}$ of concentrated hydrochloric acid and fumed to dryness. The final residue was redissolved in $10 \mathrm{ml}$ of $0.05 \mathrm{M}$ hydrochloric acid. Subsamples of this digest were taken for the analysis of $\mathrm{Fe}, \mathrm{Mn}$,

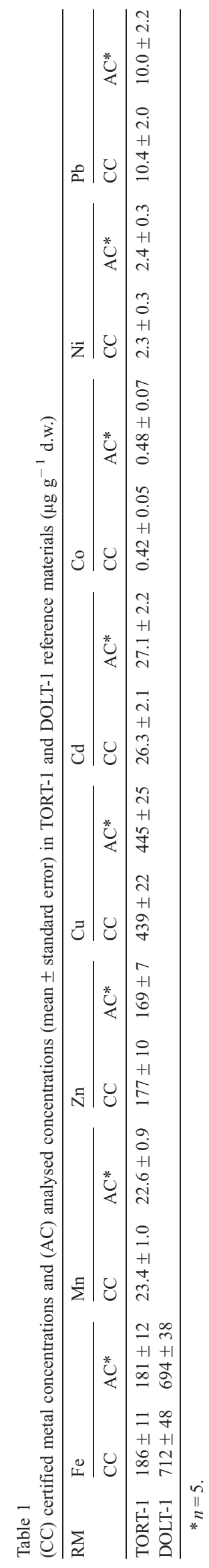


$\mathrm{Zn}, \mathrm{Cu}, \mathrm{Cd}, \mathrm{Ni}, \mathrm{Co}$ and $\mathrm{Pb}$ by flame atomic absorption spectrophotometry.

Samples for metal analysis in the soft tissues and shells were batch-analysed in random sequence (10 per batch) to remove analytical bias from the intra- and inter-population comparability studies. During measurements, the calibration was rechecked every 10 samples with a "running" standard.

All the concentrations in the soft tissues were validated with reference materials: lobster hepatopancreas TORT-I and fish liver DOLT-1 (National Research Council Canada), using the same digestion method as applied for the samples. DOLT-1 was used only for iron. The certified and analysed concentrations in the standard reference material and samples are expressed in $\mu \mathrm{g} \mathrm{g}^{-1}$ dry weight (d.w.) (Table 1). In the absence of an analytical reference material for marine biogenic carbonate, the analyses of the shells were performed against an internal reference standard consisting of a homogeneous fine powder of the shells of 30 specimens of the common limpet, Patella vulgata (Foster and Chacko, 1995; Watson et al., 1995). The mean concentrations ( \pm standard error) from 10 individual analyses of this powder were: $18.9 \pm 0.2,58.3 \pm 0.2$ and $4.0 \pm 0.1 \mu \mathrm{g} \mathrm{g}^{-1}$ expressed on dry weight basis for iron, manganese and zinc, respectively. The $\mathrm{Cu}, \mathrm{Cd}, \mathrm{Co}, \mathrm{Ni}$ and $\mathrm{Pb}$ concentrations in the samples and internal reference standard of shells were not detected since they were below the detection limit obtained for the used flame atomic absorption method $\left(<0.1 \mu \mathrm{g} \mathrm{g}^{-1}\right)$.

\subsection{Statistical analysis}

Data were treated by using the coefficient of correlation ( $r$ ) between variables, the Student's $t$-test to determine the significant differences between the metal concentrations set to a level of $99 \%$ of significance.

\section{Results}

3.1. Metal concentrations in the soft tissues and shells of $P$. aspera at CMS

Data on soft tissues weight, shell weight, shell length and concentrations of $\mathrm{Fe}, \mathrm{Mn}, \mathrm{Zn}, \mathrm{Cu}, \mathrm{Cd}, \mathrm{Ni}, \mathrm{Co}$ and $\mathrm{Pb}$ in the soft tissues of 25 individuals of $P$. aspera distributed through the available size range $(21.2-48.6 \mathrm{~mm})$, collected at CMS are presented in Table 2.

For all the determined elements in the soft tissues, there was significant variation from specimen to specimen, particularly evident for iron and manganese concentrations $(42 \%$ and $53 \%$ of coefficient of variation, respectively) (Table 2). The mean iron concentration in the soft tissues (1022 $\left.\mu \mathrm{g} \mathrm{g}^{-1}\right)$ was much greater than that of the other metals. The metal concentrations in the soft tissues decreased according to the sequence: $\mathrm{Fe}>>\mathrm{Zn}>\mathrm{Mn}>\mathrm{Cu} \sim \mathrm{Cd}>\mathrm{Ni} \sim \mathrm{Co}>\mathrm{Pb}$. From those, only zinc showed a significant negative relationship with soft tissues weight (STW), ranging from 0.10 to $0.81 \mathrm{~g}$ (Table 2 ), as described by Cravo et al. (submitted for publication) and expressed by the following equation: $\mathrm{Zn}=$ $-23.8 \times \ln (\mathrm{STW})+34.2$.

Concerning the shells, of all the studied metals, only iron, manganese and zinc were detected (Table 2). From those, zinc registered the lowest concentrations (4.2 to 9.0 $\left.\mu \mathrm{g} \mathrm{g}^{-1}\right)$ and a higher coefficient of variation $(21 \%)$ than iron and manganese (10\% and $11 \%$, respectively). Metal concentrations in the shells decreased in the order: $\mathrm{Fe}>\mathrm{Mn} \approx \mathrm{Zn}$, revealing a change in metal concentrations as well as a decrease in the coefficient of variation when compared with the whole soft tissues (Table 2). However, manganese and zinc concentrations exponentially decreased with the increase in shell growth $(W)$, ranging from 0.63 to $7.30 \mathrm{~g}$ (Table 2), as described in Cravo et al. (2002):

Table 2

Soft tissues weight $(\mathrm{g})$, shell weight $(\mathrm{g})$, shell length $(\mathrm{mm})$ and metal concentrations (in $\mu \mathrm{g} \mathrm{g}^{-1}$; mean \pm standard deviation, minimum (min) and maximum (max), \% of coefficient of variation $(\% \mathrm{CV}))$ in P. aspera $(n=25)$ from CMS

\begin{tabular}{|c|c|c|c|c|c|c|c|c|c|}
\hline & \multicolumn{4}{|l|}{ Soft tissues } & \multicolumn{4}{|l|}{ Shells } & \multirow[t]{2}{*}{$\mathrm{PF}$} \\
\hline & Mean \pm S.D. & Min & $\operatorname{Max}$ & $\% \mathrm{CV}$ & Mean \pm S.D. & Min & Max & $\% \mathrm{CV}$ & \\
\hline $\begin{array}{c}\text { Soft tissues } \\
\text { weight }\end{array}$ & $0.36 \pm 0.21$ & 0.10 & 0.81 & 60 & & & & & \\
\hline Shell weight & & & & & $3.07 \pm 1.92$ & 0.63 & 7.30 & 63 & \\
\hline Shell length & & & & & $36.0 \pm 8.5$ & 21.2 & 48.6 & 24 & \\
\hline $\mathrm{Fe}$ & $1022 \pm 431$ & 393 & 2152 & 42 & $26.7 \pm 3.7$ & 21.7 & 31.6 & 10 & 38.3 \\
\hline $\mathrm{Mn}$ & $10.6 \pm 5.6$ & 3.9 & 22.4 & 53 & $7.2 \pm 0.8$ & 6.2 & 9.3 & 11 & 1.5 \\
\hline $\mathrm{Zn}$ & $62.2 \pm 22.3$ & 36.1 & 114.2 & 35 & $5.6 \pm 1.2$ & 4.2 & 9.0 & 21 & 11.1 \\
\hline $\mathrm{Cu}$ & $6.2 \pm 1.2$ & 3.5 & 9.2 & 19 & nd & & & & \\
\hline $\mathrm{Cd}$ & $6.0 \pm 1.7$ & 3.5 & 9.1 & 28 & nd & & & & \\
\hline Co & $4.3 \pm 1.4$ & 1.7 & 6.9 & 31 & nd & & & & \\
\hline $\mathrm{Ni}$ & $4.4 \pm 1.4$ & 1.8 & 7.2 & 31 & nd & & & & \\
\hline $\mathrm{Pb}$ & nd & & & & nd & & & & \\
\hline
\end{tabular}

$\mathrm{nd}=<0.1 \mu \mathrm{g} \mathrm{g}^{-1}$, below the limit of detection of flame atomic spectrophotometry.

$\mathrm{PF}=$ ratio of mean metal concentration in the soft tissues/mean metal concentration in the shells. 
$[\mathrm{Mn}]=7.87 \times W^{-0.12}(r=-0.80 ; p<0.01) ;$ $[\mathrm{Zn}]=6.61 \times W^{-0.22}(r=-0.86 ; p<0.01)$.

\subsection{Metal concentrations in the soft tissues and shells of $P$. aspera at ECS}

Data on soft tissues weight, shell weight, shell length and concentrations of $\mathrm{Fe}, \mathrm{Mn}, \mathrm{Zn}, \mathrm{Cu}, \mathrm{Cd}, \mathrm{Ni}, \mathrm{Co}$ and $\mathrm{Pb}$ in the soft tissues of 25 individuals of $P$. aspera distributed through the available size range $(21.3-51.1 \mathrm{~mm})$, collected at ECS, are presented in Table 3. It is interesting to note that despite the ranges of shell length and shell weight were similar $(p>0.01)$ at both sampling sites (Tables 2 and 3$)$ at ECS the soft tissues weight range $(0.10-1.92 \mathrm{~g})$ was significantly higher $(p<0.01)$ than at CMS $(0.10-0.81 \mathrm{~g})$.

It is clear from Table 3 that, as observed at CMS, for all the determined metals there was considerable variation in the soft tissues, particularly evident for iron and manganese (398 to $3101 \mu \mathrm{g} \mathrm{g}^{-1}$ and 5.1 to $86.3 \mu \mathrm{g} \mathrm{g}^{-1} ; 47 \%$ and $77 \%$ of coefficient of variation, respectively). At ECS, also as observed at $\mathrm{CMS}, \mathrm{Pb}$ was not detected and the mean metal concentrations in the soft tissues change a little from that observed at CMS. From those detected, Cd concentrations were minimal and metal concentrations decreased in the order: $\mathrm{Fe}>\mathrm{Zn}>\mathrm{Mn}>\mathrm{Cu}>\mathrm{Ni} \sim \mathrm{Co}>\mathrm{Cd}>\mathrm{Pb}$. Conversely to that found at CMS, all the elements except zinc decreased logarithmically with body weight, as described by Cravo et al. (submitted for publication).

Concerning the metal concentrations in the shells, as found at the CMS, only Fe, Mn and $\mathrm{Zn}$ were detected and a relatively high variation from specimen to specimen for those metals was also found. Relatively to the mean metal concentrations in the shells the sequence noted for the CMS was different from that observed at the ECS, i.e. $\mathrm{Mn}>\mathrm{Fe}>\mathrm{Zn}$. Additionally, the heterogeneity for iron and manganese in shells was higher than at CMS. For manganese, the concentrations ranged from 24.1 to $130.5 \mu \mathrm{g} \mathrm{g}^{-1}$ and recorded $56 \%$ of coefficient of variation while zinc and iron registered lower mean concentrations and lower coefficients of variation $(16 \%$, Table 2) than manganese. Manganese was the only metal that showed significant shell weight $(W)$ dependency: $[\mathrm{Mn}]=75.80 \times W^{-0.46}$ $(r=-0.70 ; p<0.01)$ (Cravo et al., 2002). The shell weight ranged from 0.45 to $7.33 \mathrm{~g}$.

\subsection{Comparison of metal concentrations between the soft tissues and shells of P. aspera at the two sites}

The metal concentrations found in both the soft tissues and shells at the two sampling sites revealed that:

(i) At each of the sampling sites the variability in metal concentrations from individual to individual is much lower with respect to the concentrations in the shell than in the soft tissues (Tables 2 and 3).

(ii) The concentrations in the soft tissues decreased in the order $\mathrm{Fe}>\mathrm{Zn}>\mathrm{Mn}$ while in the shells decreased in the order $\mathrm{Fe} \geq \mathrm{Mn}>\mathrm{Zn}$.

(iii)

(a) The concentrations of iron and zinc were consistently lower in the shells than in the soft tissues.

(b) With respect to manganese, the concentrations were similar or even significantly higher $(p<0.01)$ in the shell than in the soft tissues, which was particularly evident at ECS.

(c) Copper, cadmium, nickel and cobalt were only detected in the soft tissues.

(iv) At ECS, the concentrations of iron and manganese in the shells were significantly higher than at CMS $(p<0.01)$. In contrast, zinc concentrations were not significantly different between sites $(p>0.01)$. In the soft tissues, iron, manganese, zinc, copper, and nickel concentrations were significantly higher than those in

Table 3

Soft tissues weight $(\mathrm{g})$, shell weight $(\mathrm{g})$, shell length ( $\mathrm{mm}$ ) and metal concentrations (in $\mu \mathrm{g} \mathrm{g}^{-1}$; mean \pm standard deviation, minimum (min) and maximum (max), \% of coefficient of variation $(\% \mathrm{CV}))$ in P. aspera $(n=25)$ from ECS

\begin{tabular}{|c|c|c|c|c|c|c|c|c|c|}
\hline & \multicolumn{4}{|l|}{ Soft tissues } & \multicolumn{4}{|l|}{ Shells } & \multirow[t]{2}{*}{$\mathrm{PF}$} \\
\hline & Mean \pm S.D. & Min & Max & $\% \mathrm{CV}$ & Mean \pm S.D. & Min & Max & $\% \mathrm{CV}$ & \\
\hline $\begin{array}{l}\text { Soft tissues } \\
\text { weight }\end{array}$ & $0.76 \pm 0.50$ & 0.10 & 1.92 & 66 & & & & & \\
\hline Shell weight & & & & & $3.62 \pm 2.15$ & 0.45 & 7.33 & 59 & \\
\hline Shell length & & & & & $37.3 \pm 8.0$ & 21.3 & 51.1 & 21 & \\
\hline $\mathrm{Fe}$ & $1466 \pm 689$ & 398 & 3101 & 47 & $44.9 \pm 7.3$ & 37.3 & 70.5 & 16 & 32.7 \\
\hline $\mathrm{Mn}$ & $25.6 \pm 19.8$ & 5.1 & 86.3 & 77 & $52.5 \pm 29.3$ & 24.1 & 130.5 & 56 & 0.5 \\
\hline $\mathrm{Zn}$ & $128.8 \pm 27.8$ & 73.4 & 172.0 & 22 & $5.3 \pm 0.9$ & 3.5 & 7.2 & 16 & 24.5 \\
\hline $\mathrm{Cu}$ & $8.1 \pm 2.9$ & 4.2 & 15.2 & 36 & nd & & & & \\
\hline $\mathrm{Cd}$ & $1.6 \pm 0.4$ & 1.0 & 2.6 & 23 & nd & & & & \\
\hline Co & $4.1 \pm 1.2$ & 2.3 & 8.0 & 29 & nd & & & & \\
\hline $\mathrm{Ni}$ & $5.8 \pm 1.9$ & 2.9 & 11.3 & 33 & nd & & & & \\
\hline $\mathrm{Pb}$ & nd & & & & nd & & & & \\
\hline
\end{tabular}

$\mathrm{nd}=<0.1 \mu \mathrm{g} \mathrm{g}^{-1}$, below the limit of detection of flame atomic spectrophotometry.

$\mathrm{PF}=$ ratio of mean metal concentration in the soft tissues/mean metal concentration in the shells. 


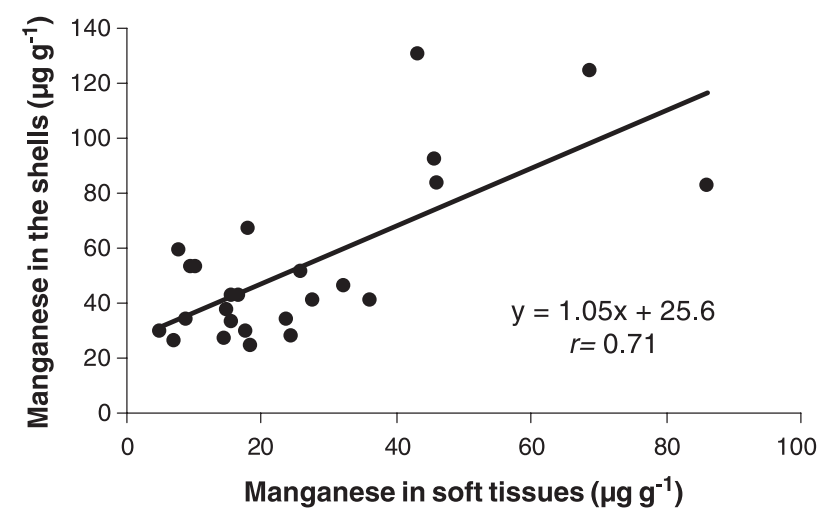

Fig. 2. Relationship between manganese concentrations in the shell and manganese concentrations in the soft tissues at ECS $(p<0.01)$.

the limpets taken from CMS $(p<0.01)$ while cadmium concentrations were significantly lower than at CMS $(p<0.01)$.

(v) The partitioning factors, PF, (defined as the ratio between the mean metal concentration in soft tissue and the mean metal concentration in shell) for the three
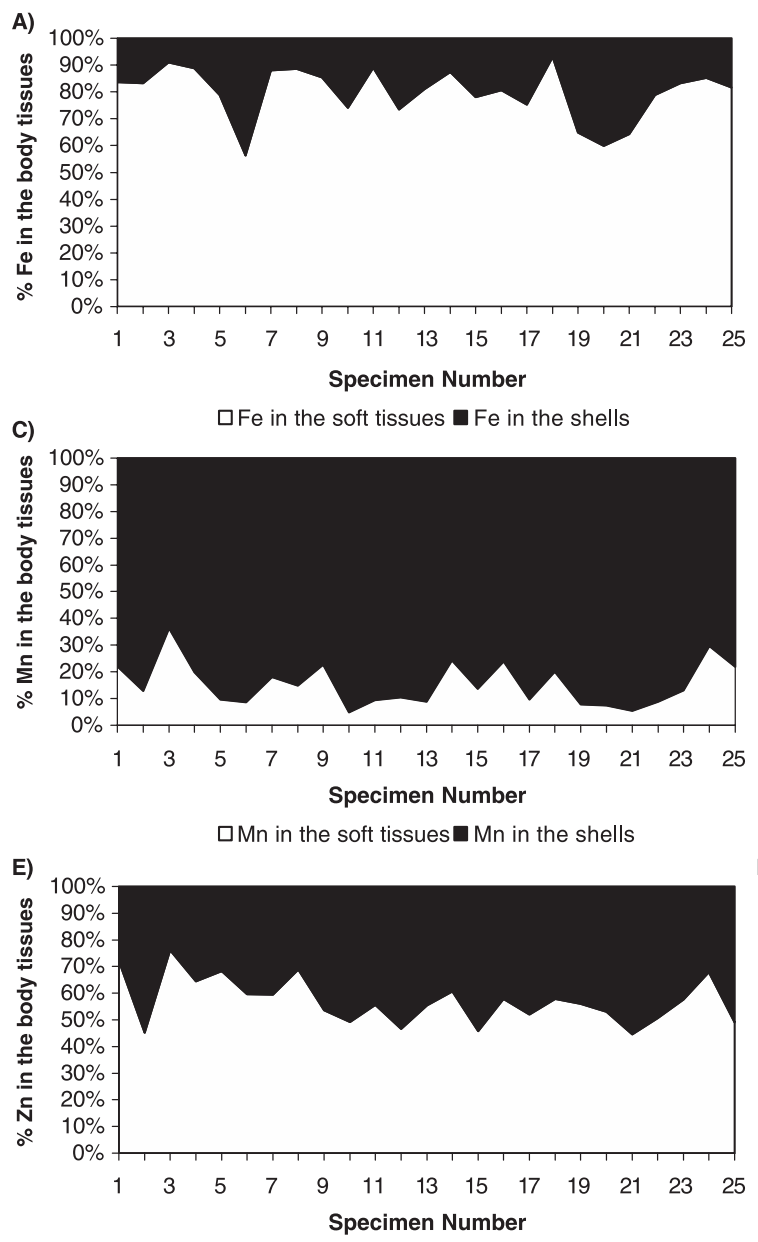

$\square \mathrm{Zn}$ in the soft tissues $\mathbf{Z n}$ in the shells elements $\mathrm{Fe}, \mathrm{Zn}$ and $\mathrm{Mn}$ in both populations (Table 2) show that:

(a) The PF values of iron (32.7-38.3) and of zinc $(11.1-24.5)$ were higher than those of manganese $(0.5-1.5)$.

(b) The PF of iron $(>30)$ are greater than those for zinc (11.1-24.5) indicating that it is far easier for iron to be incorporated into the soft tissues rather than in the shell.

(c) The PF of iron do not vary considerably from one environment to another. In contrast, the PF of zinc at ECS is two times that found at CMS.

(d) In contrast to iron and zinc, manganese shows a much greater propensity to be incorporated into the shell. The PF among sites varied from 1.5 at CMS to 0.5 at ECS and was the only metal to exhibit a significant relationship between the element concentration in the shell and the element in the soft tissues at ECS (Fig. 2).

In order to determine and understand which of the soft tissues or shells can represent a major metal reservoir, the
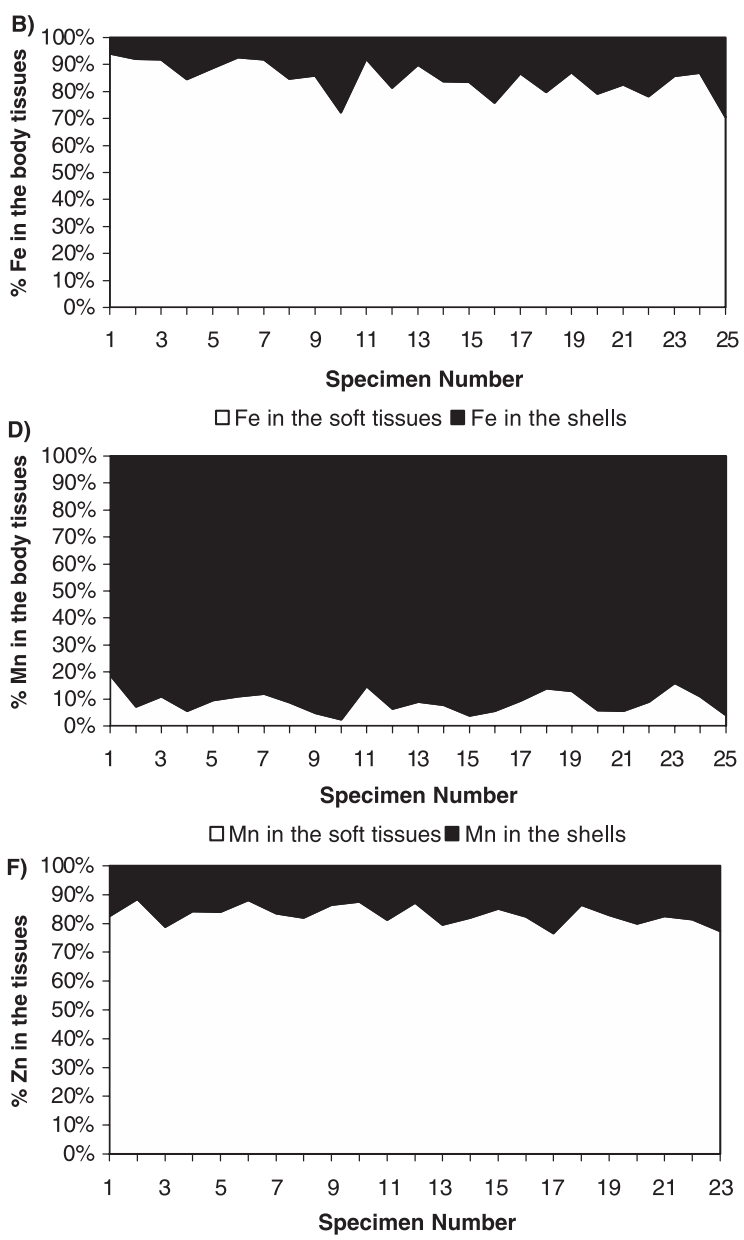

$\square \mathrm{Zn}$ in the soft tissues $\mathrm{Zn}$ in the shells

Fig. 3. Partitioning of metals between soft tissues and shells expressed in percentage of the total amount of metals incorporated in both tissues at: (A) Fe at CMS; (B) Fe at ECS; (C) Mn at CMS; (D) Mn at ECS; (E) $\mathrm{Zn}$ at CMS and (F) $\mathrm{Zn}$ at ECS. 
percentage distribution of the total amount of iron, manganese and zinc incorporated in both tissues at both sites was calculated and shown in Fig. 3. At CMS, in the soft tissues the average percentage of iron was significantly higher $(80 \%)$ than in the shells $(20 \%)$ (Fig. 3A). However, at ECS despite of the average percentage of iron (85\%) (Fig. 3B) was slightly higher than at CMS, the difference between both sites was not significant ( $p>0.01)$. For manganese and zinc, the situation changed; there were significant differences between sites. For manganese, the average percentage at CMS was significantly higher in the shells (85\%) than in the soft tissues (15\%), (Fig. 3C) and the percentage at ECS $(91 \%)$ was significantly higher $(p<0.01)$ than at the CMS (Fig. 3D). For zinc, the average percentage at CMS was similarly distributed in both tissues $(57 \%$ in the soft tissues and $43 \%$ in the shells) (Fig. 3E); however, at ECS the average percentage in the soft tissues $(83 \%)$ was significantly higher than in the shells (17\%) (Fig. 3F) and consequently significantly different $(p<0.01)$ from the former site.

\section{Discussion}

4.1. Inter-population variability of metal concentrations in the soft tissues and shells of P. aspera

Data that compare metal concentrations in the soft tissues of $P$. aspera are sparse. Only two papers have reported data for $P$. aspera individuals collected from Milos Island, in the Aegean Sea off Greece (Catsiki et al., 1991) and from the south-southeast coast of Portugal (Miguel et al., 1999). A comparison of the mean metal concentrations in the soft tissues of $P$. aspera with other Patella species from a wide range of geographical locations and different environmental regimes is presented in Table 4 .

It is clear from Table 4 that for each trace metal, its concentrations associated with the soft tissues vary over a considerably wide range and a number of general points can be observed. In all Patella species, there is a general tendency for iron and zinc to be preferentially incorporated into the soft tissues, as usually found in other marine

Table 4

Trace metal concentrations $\left(\mu \mathrm{g} \mathrm{g}^{-1}\right.$ ) in the soft tissues of $P$. aspera determined in present work and in Patella sp. from other geographical locations

\begin{tabular}{|c|c|c|c|c|c|c|c|c|}
\hline Metal concentrations & $\mathrm{Fe}$ & $\mathrm{Mn}$ & $\mathrm{Zn}$ & $\mathrm{Cu}$ & $\mathrm{Cd}$ & $\mathrm{Ni}$ & $\mathrm{Co}$ & Reference \\
\hline Patella aspera-CMS & 1022 & 10.6 & 62.3 & 6.1 & 6.0 & 4.4 & 4.3 & This work \\
\hline Patella aspera-ECS & 1466 & 25.6 & 128.8 & 8.1 & 1.6 & 5.8 & 4.1 & This work \\
\hline $\begin{array}{l}\text { Patella aspera (Central Aegean Sea, } \\
\text { Milos Island, Greece-three clean stations) }\end{array}$ & & $11.3-32.1$ & $31.9-56.5$ & $7.6-12.0$ & $3.7-11.4$ & $19.1-28.6$ & & $\begin{array}{l}\text { Catsiki et al. } \\
\text { (1991) }\end{array}$ \\
\hline $\begin{array}{l}\text { Patella aspera (Central Aegean Sea, } \\
\text { Milos Island, Greece, semi-enclosed gulf } \\
\text { including the port) }\end{array}$ & & 23.0 & 43.2 & 7.9 & 5.0 & 16.0 & & $\begin{array}{l}\text { Catsiki et al. } \\
(1991)\end{array}$ \\
\hline Patella aspera (SW Algarvian coast, Portugal) & 1099 & 10.2 & 180 & 4.7 & 4.7 & & & $\begin{array}{l}\text { Miguel et al. } \\
(1999)\end{array}$ \\
\hline $\begin{array}{l}\text { Patella aspera (Sagres-SW Algarvian coast, } \\
\text { Portugal) }\end{array}$ & 581 & 6.1 & 165 & 3.5 & 5.3 & 0.2 & & $\begin{array}{l}\text { Miguel et al. } \\
\text { (1999) }\end{array}$ \\
\hline $\begin{array}{l}\text { Patella aspera (Mouth of Arade River, } \\
\text { S Algarvian coast, Portugal) }\end{array}$ & 1317 & 11.8 & 298 & 5.9 & 1.9 & 0.3 & & $\begin{array}{l}\text { Miguel et al. } \\
\text { (1999) }\end{array}$ \\
\hline $\begin{array}{l}\text { Patella aspera (Vilamoura Marina, } \\
\text { S Algarvian coast, Portugal) }\end{array}$ & 1012 & 8.5 & 154 & 6.2 & 1.7 & 0.3 & & $\begin{array}{l}\text { Miguel et al. } \\
\text { (1999) }\end{array}$ \\
\hline Patella vulgata (Fal estuary, several stations) & $952-2821$ & $3.4-25.1$ & $155-331$ & $15.6-225$ & $3.3-7.4$ & $1.2-1.9$ & $0.8-4.1$ & $\begin{array}{l}\text { Bryan et al. } \\
(1985)\end{array}$ \\
\hline Patella vulgata (Bristol Channel, several stations) & $1160-2361$ & $6-102$ & $81-476$ & $5.1-59$ & $2.7-289$ & $1.1-4.5$ & $<0.1-2.4$ & $\begin{array}{l}\text { Bryan et al. } \\
(1985)\end{array}$ \\
\hline $\begin{array}{l}\text { Patella vulgata (Nuclear fuel reprocessing } \\
\text { La Haugue, France) }\end{array}$ & 1206 & & 64 & 4.7 & 3.6 & 1.3 & 0.2 & $\begin{array}{l}\text { Miramand and } \\
\text { Bentley (1992) }\end{array}$ \\
\hline $\begin{array}{l}\text { Patella vulgata (Alexandria waters, } \\
\text { Mediterranean-domestic sewage influence) }\end{array}$ & 450 & 16.0 & 38 & 20.9 & 0.4 & & & $\begin{array}{l}\text { El-Rayis and } \\
\text { Ezzat }(1986)\end{array}$ \\
\hline $\begin{array}{l}\text { Patella vulgata (Alexandria waters, } \\
\text { Mediterranean-two stations, domestic }+ \\
\text { industrial sewage influence) }\end{array}$ & $504-1239$ & $14-17$ & $38-63$ & $20.7-22.9$ & $0.5-0.9$ & & & $\begin{array}{l}\text { El-Rayis and } \\
\text { Ezzat (1986) }\end{array}$ \\
\hline Patella caerulea (Follonica Bay, Italy) & $103-331$ & $10.6-46.2$ & $63-104$ & $7.7-12.5$ & $0.8-4.6$ & $1.2-4.7$ & & $\begin{array}{l}\text { Bargagli et al. } \\
(1985)\end{array}$ \\
\hline $\begin{array}{l}\text { Patella caerulea (viscera) } \\
\quad \text { (ferro-nickel smelter, Greece) }\end{array}$ & & 8.1 & 180 & 27.1 & & & 0.5 & $\begin{array}{l}\text { Nicolaidou and } \\
\text { Nott }(1990)\end{array}$ \\
\hline $\begin{array}{l}\text { Patella caerulea (Cap de Nice, Alpes Maritimes, } \\
\text { France) }\end{array}$ & & & $16-120$ & & & & & Puel et al. (1987) \\
\hline Patella sp. (Turkish coast, sewage influence) & $891-1512$ & & $44.8-96.0$ & $1.4-13.7$ & $2.5-30.3$ & $2.5-14.6$ & & Ramelow (1985) \\
\hline $\begin{array}{l}\text { Patella } \text { sp. (Turkish coast, not influenced } \\
\text { by sewage) }\end{array}$ & $929-1257$ & & $39.9-58.9$ & $3.1-11.6$ & $1.1-8.4$ & $7.6-83.7$ & & Ramelow (1985) \\
\hline $\begin{array}{l}\text { Range of metal concentrations in the soft parts } \\
\text { of molluscs }\end{array}$ & $110-5000$ & $5-150$ & $50-500$ & $3-12$ & $1-5$ & $2-5$ & $1-3$ & $\begin{array}{l}\text { Depledge et al. } \\
\text { (1994) }\end{array}$ \\
\hline
\end{tabular}


gastropods (Depledge et al., 1994; Brown and Depledge, 1998). Patella sp. in general are characterised by a high concentration of iron in the soft tissues which may be ascribed to the fact that iron is a constituent of goethite $(\alpha-\mathrm{FeOOH})$ present in the radula of Patellidae (Runham et al., 1969; Mann, 1988; Fish and Fish, 1989). Relatively to zinc, high concentrations were previously noted by other authors for bivalves such as Mytilus spp. and oysters, as well as other gastropods (Carriker et al., 1980; Koide et al., 1982; Martincic et al., 1984; Szefer and Szefer, 1985, 1990; Puel et al. 1987; Babukutty and Chacko, 1992; Walsh et al., 1995; Giusti et al., 1999; de Wolf et al., 2001).

However, metal concentrations in the soft tissues of $P$. aspera affected by sewage discharges when compared to those of other Patella sp., taken from sites influenced by industrial discharges, cannot be considered elevated.

Nevertheless, data on trace metal concentrations in the soft tissues of $P$. aspera showed differences between sampling sites. Data from ECS provide an assessment of the organism's response to waters where the quality is seriously impaired by the discharge of domestic sewage. The concentrations of iron, manganese, zinc, copper, and nickel in the soft tissues of the animals from CMS were significantly lower than those in the limpets taken from ECS $(p<0.01)$. In contrast, cadmium concentrations in the soft tissues of $P$. aspera at CMS were significantly higher than at ECS $(p<0.01)$. This issue is discussed in Cravo et al. (submitted for publication) and was associated with the higher bioavailability of cadmium at CMS induced by the lithological differences between sites. At the CMS site coastal rocks are predominantly schists, relatively enriched in cadmium whereas at ECS calcareous rocks predominate (Bebianno et al., 2003).

From this comparison, it is tempting to conclude that the elevated iron, manganese, zinc, copper and nickel concentrations associated with the ECS limpet population are a direct reflection of the availability of metals by the impact of sewage contamination, what, however, was not observed in respect to cadmium.

Zinc in the soft tissues of $P$. aspera showed the best response in monitoring the environmental level of metals. The mean zinc concentration in the tissues was at least one order of magnitude greater than those of $\mathrm{Mn}, \mathrm{Cu}, \mathrm{Cd}, \mathrm{Ni}$ and Co and was significantly higher at ECS than at CMS (about two fold). At ECS, the increase of all the other metal concentrations in limpets tissues induced by domestic sewage discharges was, where evident, not particularly amplified. However, at ECS, where higher zinc concentrations were observed, it can be considered partly regulated. At this sampling site, in the soft tissues the lowest coefficient of variation was found for this metal (Table 2) and no relationship between zinc concentrations and soft tissues weight was detected. Nevertheless, this difference between populations seems extremely useful for assessing the impact of zinc once mussels that are more commonly used in biomonitoring studies regulate zinc concentrations in their tissues.
Concerning the shells of marine molluscs they are predominantly composed of calcium carbonate in the form of calcite or aragonite or a mixture of both polymorphs. Calcium has an ionic radius of $0.099 \mathrm{~nm}$ and other metals with radii less than calcium $\left(\mathrm{Fe}^{2+}, \mathrm{Fe}^{3+}, \mathrm{Cu}^{2+}, \mathrm{Mn}^{2+}\right.$, $\mathrm{Zn}^{2+}$ ) always form hexagonal carbonates isostructural with calcite. The increase of some elements in the shell of marine molluscs has been noted in response to increases of environment metal concentrations (Carriker et al., 1980; Walsh et al., 1995; Giusti et al., 1999, de Wolf et al., 2001).

Data in the literature that compare trace metal concentrations in the shells of Patella sp. are, as for the soft tissues, also sparse. The importance of the polymorphic form of calcium carbonate upon the chemical composition of a shell is illustrated in Table 5. Iron and zinc concentrations in $P$. vulgata from the Irish Sea (Segar et al., 1971) were dramatically higher than for other species and sites. However, apart from those values, metal concentrations in the present work showed no particular enhancement in comparison with those in Patella sp. from other sites of the world, either clean sites or sites influenced by sewage discharges. Even so, metal concentrations associated with the shell of $P$. aspera and P. vulgata are sensitive to changes in environmental conditions, particularly in the case of manganese and to a lesser extent in the case of iron.

At CMS, metal concentrations in the shells decreased according to: $\mathrm{Fe}>\mathrm{Mn}>\mathrm{Zn}$. At ECS due to the preferential incorporation of manganese in the shell, these metal concentrations were more important than those of iron and zinc and therefore the order was $\mathrm{Mn}>\mathrm{Fe}>\mathrm{Zn}$. Zinc concentrations in the shell do not show any difference between sites and even if they represent a direct reflection of zinc in the environment, there was little more than the intra-variability recorded amongst shells (Tables 2 and 3). Only manganese concentrations in the shell exhibited large, consistent and significant differences between both sites. The works by Foster and Chacko (1995) for P. vulgata, Ireland and Wootton (1977) for the gastropods Thais lapillus and $L$. littorea, Bourget (1974) and Watson (1993) for barnacles (Table 5) attest that the manganese concentrations in shells are particularly sensitive to differences in environmental concentrations.

\subsection{Comparison of metal concentrations between the soft tissues and shells of P. aspera}

The present work provides a preliminary snapshot of partitioning of the three trace metals, $\mathrm{Fe}, \mathrm{Mn}$ and $\mathrm{Zn}$ between the soft tissues and the shell of $P$. aspera distributed through the available size range at two contrasting sites. At each of the sites the variability in metal concentrations is much lower in the shell than in the soft tissues which is in accordance with the fact that metal variability in the shells is less associated with weight, size, season, physiological condition, etc., than in the soft tissues (Lingard et al., 1992). The data revealed that the soft tissues and 
Table 5

Trace metal concentrations $\left(\mu \mathrm{g}^{-1}\right.$ ) in the shells of $P$. aspera (present work) and in Patella sp. from other geographical locations and in other gastropods with mixed mineralogy

\begin{tabular}{|c|c|c|c|c|}
\hline & \multicolumn{3}{|c|}{ Metals $\left(\mu \mathrm{g} \mathrm{g}^{-1}\right)$} & \multirow[t]{2}{*}{ Reference } \\
\hline & $\mathrm{Mn}$ & $\mathrm{Fe}$ & $\mathrm{Zn}$ & \\
\hline \multicolumn{5}{|l|}{ Patella aspera } \\
\hline CMS & 7.2 & 26.7 & 5.6 & This work \\
\hline ECS & 52.5 & 44.9 & 5.3 & This work \\
\hline \multicolumn{5}{|l|}{ Calcitic shells } \\
\hline \multicolumn{5}{|l|}{ Patella vulgata } \\
\hline Menai Bridge (UK) & 61.6 & 19.2 & 4.0 & $\begin{array}{l}\text { Foster and Chacko } \\
\text { (1995) }\end{array}$ \\
\hline $\begin{array}{l}\text { Dulas Bay (mine } \\
\text { drainage } \\
\text { influence, UK) }\end{array}$ & 57.3 & 17.6 & 4.1 & $\begin{array}{l}\text { Foster and Chacko } \\
\text { (1995) }\end{array}$ \\
\hline $\begin{array}{l}\text { Hen Borth } \\
\text { ("baseline", UK) }\end{array}$ & 19.5 & 9.9 & 3.5 & $\begin{array}{l}\text { Foster and Chacko } \\
\text { (1995) }\end{array}$ \\
\hline Irish Sea (UK) & 8.6 & 430 & 51 & Segar et al. (1971) \\
\hline Norway & & $39-64$ & $3-18$ & Lande (1977) \\
\hline Weymouth (UK) & & & & Bowen (1956) \\
\hline $\begin{array}{l}\text { Tel-Aviv, Israel } \\
\text { (direct sewage } \\
\text { influence) }\end{array}$ & 5.5 & & 5.8 & Navrot et al. (1974) \\
\hline $\begin{array}{l}\text { Tel-Aviv, Israel } \\
\text { (less sewage } \\
\text { influence) }\end{array}$ & $5.1-7.1$ & & $4.7-8.6$ & Navrot et al. (1974) \\
\hline \multicolumn{5}{|l|}{ Patella coerulea } \\
\hline France & & & $3-47$ & Puel et al. (1987) \\
\hline \multicolumn{5}{|l|}{ Semibalanus balanoides } \\
\hline Menai Bridge (UK) & 270 & & 20 & Watson (1993) \\
\hline Dulas Bay (UK) & 281 & & 53 & Watson (1993) \\
\hline \multicolumn{5}{|c|}{ Shells of mixed mineralogy } \\
\hline $\begin{array}{l}\text { Nerita albicilla (Phuket } \\
\text { Island, Thailand) }\end{array}$ & 9.1 & 30.8 & 5.8 & Foster et al. (1997) \\
\hline Nerita albicilla (India) & 5.9 & 37.7 & 6.8 & Badran (1993) \\
\hline Nerita albicilla (Kenya) & 17.3 & 27.6 & 7.7 & Badran (1993) \\
\hline $\begin{array}{l}\text { Nerita albicilla } \\
\quad \text { (Mauritius) }\end{array}$ & 4.6 & 21.1 & 4.3 & Badran (1993) \\
\hline $\begin{array}{l}\text { Nerita albicilla } \\
\quad \text { (Aldabra) }\end{array}$ & 0.7 & 28.7 & 3.3 & Badran (1993) \\
\hline $\begin{array}{l}\text { Nerita polita (Phuket } \\
\text { Island, Thailand) }\end{array}$ & 3.4 & 20.8 & 4.1 & Foster et al. (1997) \\
\hline $\begin{array}{l}\text { Nerita costata (Phuket } \\
\text { Island, Thailand) }\end{array}$ & 5.3 & 21.5 & 5.2 & Foster et al. (1997) \\
\hline $\begin{array}{l}\text { Nerita undata (Phuket } \\
\text { Island, Thailand) }\end{array}$ & 3.6 & 32.6 & 4.6 & Foster et al. (1997) \\
\hline
\end{tabular}

shells of $P$. aspera accumulate the bioavailable metals in the environment in very different ways.

The concentrations of iron were consistently lower in the shells than in the soft tissues $(\mathrm{PF}=32.7-38.3)$. The same was found even in oysters (Carriker et al., 1980), clams (ElNady, 1996), mussels Mytilus edulis (Giusti et al., 1999; Szefer et al., 2002) and the gastropod L. sabra (de Wolf et al., 2001). In contrast for limpets P. vulgata (Segar et al., 1971), gastropods T. lapillus and L. littorea (Ireland and Wootton, 1977) or bivalves M. edulis, Cardium glaucum and Astarte borealis (Szefer and Szefer, 1985, 1990) higher iron concentrations were found in the shells rather than in the soft tissues. In these cases, there is a suspicion that the cleaning process applied prior to analysis in the shells was inadequate.

Like for iron, zinc is preferentially found in the soft tissues $(\mathrm{PF}=11.1-24.5)$. The same was observed in the limpet $P$. coerulea (Puel et al., 1987), in oysters Crassostrea virginica (Carriker et al., 1980), in mussels M. edulis (Koide et al., 1982; Martincic et al., 1984; Szefer and Szefer, 1985, 1990; Giusti et al., 1999; Szefer et al., 2002), in clams Venerupis decussata (El-Nady, 1996) and in an estuarine bivalve Villorita cyprinoides (Babukutty and Chacko, 1992). However, the partitioning factors determined for zinc in the present study were significantly higher than those found for the gastropod $A$. constricta (1.3 to 2.8), in the Newcastle region, Australia, from an area with a commercial shipping harbour and a marine lake with high levels of recreational activities (Walsh et al., 1995).

With respect to manganese, the concentrations were generally similar or even higher in the shell than in the soft tissues $(\mathrm{PF}=0.5-1.5)$. The latter was particularly evident at ECS. Higher manganese concentrations in the shells than in soft tissues have also been found in oysters $C$. virginica (Carriker et al., 1980), mussels M. edulis (Szefer and Szefer, 1985, 1990; Szefer et al., 2002) and in the estuarine bivalve V. cyprinoides (Babukutty and Chacko, 1992). This could suggest that shells may remove manganese from the surrounding medium as pointed out by El-Nady (1996) acting as a safe storage matrix for this metal, which may be resistant to soft tissue detoxification mechanism, reducing its availability within the food chain (Walsh et al., 1995). Alternatively, this fact could also suggest that the mantle tissue takes up manganese directly from seawater (along with calcium) for incorporation into the shell, with no involvement of remaining soft tissue, and that this rate of uptake and accumulation is greater than that into the remaining soft tissues directly.

The partitioning of the elements between the two tissues is consequently sensitive to changes in environmental conditions, suggesting that the difference between populations are promoted in part or whole by the contrasting water environments to which they were exposed. Unfortunately, there are no available data on metal concentrations in the water of the sampling sites but it is known from literature that sewage effluent discharges, even in the absence of any industrial waste component, can contain considerable quantities of trace metals originated from a number of sources as the biogenic (metabolic) wastes, from consumer products used for domestic purposes (e.g. detergents formulations containing $\mathrm{Fe}, \mathrm{Mn}, \mathrm{Cr}, \mathrm{Ni}, \mathrm{Co}, \mathrm{Zn}$ ) and from corrosion of water pipes $(\mathrm{Cu}, \mathrm{Pb}, \mathrm{Zn}$ and $\mathrm{Cd})$ (Depledge et al., 1994).

The partitioning of zinc between the soft and shell tissues is much more sensitive to environmental concentrations than that for iron. The greatest differential of PF between sites was observed for this metal (11.4-24.5), indicating that in environments when the bioavailability of zinc is greater it is 
preferentially incorporated into the soft tissues. For iron despite of the PF decreasing from 38.3 at CMS to 32.7 at ECS, the difference between sites was not significant. The lowest PF value was associated with the manganese concentrations in the limpets taken from the ECS. With increasing availability of $\mathrm{Mn}^{2+}$ (due to the influence of sewage and higher impact of freshwater, this chemical form is usually higher than in seawater; Waldichuk, 1974), this form is preferentially incorporated into the shell. In fact apparently, at this site, the bioavailability of this element in $P$. aspera was higher than at CMS. At ECS there was an increase of manganese accumulation in both tissues relatively to CMS (two fold in the soft tissues and seven fold in the shells; Tables 2 and 3).

The metal amounts incorporated in both tissues were determined separately in the soft tissues and shells and these data revealed that with the increasing environmental availability of metals: (i) the soft tissues represent a major reservoir for zinc; whereas for iron there was not a significant difference between sites relatively to the mean percentage of iron incorporated in each of the tissues; (ii) the shells could represent a sink for manganese by removing a relatively higher percentage of this metal from the surrounding medium at ECS than at CMS. This confirms as suggested by Langston et al. (1998) that shells are a potential sink for metals due to their capacity to remove bioavailable metals from the environment.

With these results, it can be assumed that CMS may be representative of a reference clean site. So, when $P$. aspera population is used in metal biomonitoring studies at other sampling sites if the mean percentage of iron and zinc in the soft tissues are significantly higher than $80 \%$ and $60 \%$, respectively, or in the shells significantly higher than $85 \%$, than it can be considered that the limpets are accumulating metals in response to an increase in metal bioavailability.

The fact that at CMS no significant relationship was observed between metal concentrations in the soft tissues and shells could indicate that at this clean site, without a relevant anthropogenic disturbance the mechanism that controls metal incorporation in the soft tissues and shells is different from that at ECS. It is known that in the soft tissues essential metals are incorporated in metabolically important biomolecules (or bonded to their functional groups) with a key role in the organism such as respiratory pigments, proteins, enzymes or metalloenzymes (Bryan et al., 1985; Depledge and Bjerregaard, 1989; Rainbow, 1997) whereas in the shells metal ions may be incorporated into the carbonate crystal lattice by diadochically replacing the calcium ions in the calcite or can also be triggered by metabolic functions (Babukutty and Chacko, 1992).

However, at ECS where higher metal concentrations are available, a relationship between manganese concentration in the soft tissues and in the shells occurs. This fact contrasts with the data shown by Szefer et al. (2002) for M. edulis from the southern Baltic, where iron and zinc concentrations in both the tissues registered the same positive relationship but that was not observed for manganese. It could suggest that at ECS the excess of manganese in the soft tissues is transported/exported to the shell, due to a possible regulatory or detoxifying mechanism. However, no regulation of manganese was observed for both tissues at this site. Alternatively, it could also results from the fact that in both the soft tissues and shells a negative relationship was observed between manganese concentrations and the correspondent weight of the soft tissues and the shells.

In general, the soft tissues of $P$. aspera can be considered as a potential indicator of $\mathrm{Zn}$ (and Mn) while the shell of $P$. aspera can be considered as a potential indicator of $\mathrm{Mn}$. Relatively to copper, cadmium, nickel and cobalt, these metal concentrations were much higher in the soft tissues than in the shells $\left(<0.1 \mu \mathrm{g} \mathrm{g}^{-1}\right)$, which indicates that the shells were not a good indicator for these metals because they do not reflect the environmental bioavailability of these metals as do the soft tissues.

\section{Acknowledgements}

A. Cravo gratefully acknowledges the FCT (Portugal) for financial support, grant ref: FRMH/BD/403/92. The authors acknowledge Mrs. S. East for her technical support of the shell metal analysis.

\section{References}

Almeida, PJR. The physical oceanography of Cape São Vicente upwelling region observed from sea, land and space. PhD Thesis, University of Wales, Bangor; 1999.

Babukutty Y, Chacko J. Trace metals in an estuarine bivalve from the southwest coast of India. Ambio 1992;21(4):292-6.

Badran, MI. Shells of Nerita species, potential biological indicators of metal pollution in tropical and subtropical coastal waters. MSc Thesis, University of Wales; 1993.

Bargagli R, Baldi F, Leonzio C. Trace metal assessment in sediments, molluses and reed leaves in the bay of Follonica (Italy). Mar Environ Res 1985;16:281-300.

Bebianno MJ, Cravo A, Miguel C, Morais S. Metallothionein concentrations in a population of Patella aspera: variation with size. Sci Total Environ 2003;301:151-61.

Bourget E. Environmental and structural control of trace metals in barnacle shells. Mar Biol 1974;28:27-36.

Bourgoin BP. Mytilus edulis shell as a bioindicator of lead pollution: considerations on bioavailability and variability. Mar Ecol, Prog Ser 1990; 61(3):253-62.

Bowen HJM. Strontium and barium in sea water and marine organisms. J Mar Biol Assoc UK 1956;35:451-60.

Brix H, Lyngby JE. The influence of size upon the concentrations of Cd, $\mathrm{Cr}, \mathrm{Cu}, \mathrm{Hg}, \mathrm{Pb}$ and $\mathrm{Zn}$ in the common mussel (Mytilus edulis L.). Symp Biol Hung 1985;29:253-71.

Brown MT, Depledge MH. Determinants of trace metal concentrations in marine organisms. In: Langston W, Bebianno MJ, editors. Metal metabolism in aquatic environments. London: Chapman \& Hall; 1998. p. $185-217$.

Bryan GW, Langston WJ, Hummerstone LG, Burt GR. A guide to the assessment of heavy-metal contamination using biological indicators. J Mar Biol Assoc UK, Occas Publ 1985;4 [92 pp.]. 
Carell B, Forberg S, Grundelius E, Henrikson L, Johnels A, Lindh U, et al. Can mussel shells reveal environmental history? Ambio 1987;16: $2-10$.

Carriker MR, Palmer RE, Sick LV, Jonhson CC. Interaction of mineral elements in sea water and shell of oysters (Crassostrea virginica (Glemin)) cultured in controlled and natural systems. J Exp Mar Biol Ecol 1980;46:279-96.

Carriker MR, Swanr CP, Prezant RS, Counts III CL. Chemical elements in the aragonitic and calcitic microstructural groups of shell of the oyster Crassostrea virginica. A proton probe study. Mar Biol 1991;109(2): 279-96.

Catsiki VA, Papathanassiou E, Bei F. Heavy metal levels in characteristic benthic flora and fauna in the central Aegean Sea. Mar Pollut Bull 1991;22(11):566-9.

Cravo, A. The impact of sewage discharge in Vilamoura, Portugal. $\mathrm{PhD}$ Thesis, University of Wales, Bangor, UK; 1996.

Cravo A, Foster P, Bebianno MJ. Minor and trace elements in the shell of Patella aspera (Röding, 1798). Environ Int 2002;28(4):295-302.

Cravo, A, Bebianno, MJ, Foster, P. Biomonitoring of trace metals using Patella aspera. J Mar Biol Assoc UK [submitted for publication].

Depledge MH, Bjerregaard P. Explaining variation in trace metal concentrations in selected invertebrates: the importance of interactions between physiological state and environmental factors. In: Aldrich JC, editor. Aquatic ecotherms. Wicklow, Ireland: Japaga; 1989. p. 121-36.

Depledge MH, Weeks JM, Bjerregaard P. Heavy metals. In: Calow P, editor. Handbook of ecotoxicology, vol. 2. Oxford: Blackwell; 1994. p. $79-105$. Chapter 5 .

de Wolf H, Backeljau T, Blust R. Heavy metal accumulation in the periwinkle Littorina littorea, along a pollution gradient in the Scheldt Estuary. Sci Total Environ 2000;262(1-2):111-21.

de Wolf H, Ulomi SA, Backeljau T, Pratap HB, Blust R. Heavy metal levels in the sediments of four Dar es Salaam mangroves. Accumulation in, and effect on the morphology of the periwinkle, Littoraria scabra (Mollusca: Gastropoda). Environ Int 2001;26(4):243-9.

El-Nady FE. Heavy metals exchange among the aquatic environment of the Mediterranean coast of Egypt. Indian J Mar Sci 1996;25(3): $225-33$.

El-Rayis OA, Ezzat AA. Bioaccumulation of some heavy metals in coastal marine animals in the vicinity of Alexandria: II. Surveying. FAO Fish Rep 1986;334:67-72 [Supplement].

Ferrell RE, Carville TE, Martinez JD. Trace metals in oyster shells. Environ Lett 1973;4:311-6.

Fish JD, Fish S. A student's guide to the seashore. London: Unwin Hyman; 1989. 473 pp.

Fishelson L, Bresler V, Manelis R, Zuk-Rimon Z, Dotan A, Hornung H, et al. Toxicological aspects associated with the ecology of Donax trunculus (Bivalvia, Mollusca) in a polluted environment. Sci Total Environ 1999;226(2-3):121-31.

Foster P, Chacko J. Minor and trace elements in the shell of P. vulgata (L.). Mar Environ Res 1995;40(1):55-76.

Foster P, Chacko J, Badran MI. Minor and trace concentrations in the shells of four Nerita species (N. albicilla, N. costata, N. polita, N. undata) from Ko Phuket, Thailand. J Mar Atmos Res 1997;1(1):25-32.

Giusti L, Williamson AC, Mistry A. Biologically available trace metals in Mytilus edulis from the coast of northeast England. Environ Int 1999;25(8):968-81.

Ireland MP, Wootton RJ. Distribution of lead, zinc, copper and manganese in the marine gastropods, Thais lapillus and Littorina littorea, around the coast of Wales. Environ Pollut 1977;12:27-41.

Koide M, Lee DS, Goldberg ED. Metal and transuranic records in mussel shells, byssal threads and tissues. Estuar Coast Shelf Sci 1982;15: 679-95.

Lande E. Heavy metal pollution in Trondheimsfjorden, Norway and the recorded effects on the fauna and flora. Environ Pollut 1977;12: $187-98$.

Langston WJ, Spence K. Biological factors involved in metal concentrations observed in aquatic organisms. In: Tessier A, Turner DR, editors.
Metal speciation and bioavailability in aquatic systems. New York: Wiley; 1995. p. 407-78.

Langston WJ, Bebianno MJ, Burt GR. Metal handling strategies in molluscs. In: Langston W, Bebianno MJ, editors. Metal metabolism in aquatic environments. London: Chapman \& Hall; 1998. p. 219-83.

Lingard SM, Evans RD, Bourgoin BP. Method for the estimation of organic-bound and crystal-bound metal concentrations in bivalves shells. Bull Environ Contam Toxicol 1992;48:179-84.

Mann S. Molecular recognition in biomineralization. Nature 1988;332: $119-24$.

Martincic D, Nürnberg HW, Stoeppler M, Branica M. Bioaccumulation of heavy metals by bivalves from Lim Fjord (North Adriatic Sea). Mar Biol 1984;81:177-88.

Miguel CS, Machado LM, Bebianno MJ. Variações de Cd, Cu e Zn em mexilhões Mytilus galloprovincialis e lapas $P$. aspera ao longo da costa Algarvia (Sul de Portugal). Ecotoxicol Environ Rest 1999;2(1):1-6.

Miramand P, Bentley D. Heavy metal concentrations in two biological indicators (Patella vulgata and Fucus serratus) collected near the French nuclear reprocessing plant of La Hague. Sci Total Environ 1992;111:135-49.

Navrot J, Amiel AJ, Kronfeld J. Patella vulgata: a biological monitor of coastal metal pollution — a preliminary study. Environ Pollut 1974;7: $303-8$.

Nicolaidou A, Nott JA. Mediterranean pollution from a ferro-nickel smelter: difference uptake of metals by some gastropods. Mar Pollut Bull 1990;21(3):137-43.

Prakash NT, Naidu TS, Rao KSJ. Metals in marine waters and bivalves from the coastline of India: a review. Indian J Environ Toxicol 1994; $4: 1-5$.

Prakash NT, Rao KSJ, Sivasankaran MA, Reddy SS, Naidu TS. Metal content in the shells of green mussel, Perna viridis (L.) from east coast of India: a preliminary study. J Aquat Biol 1996;11(1-2):24-30.

Price GD, Pearce NJG. Biomonitoring of pollution by Cerastoderma edule from the British Isles: a laser ablation ICP-MS study. Mar Pollut Bull 1997;34(12):1025-31.

Puel D, Zsürger N, Breittmeyer JPh. Statistical assessment of a sampling pattern for evaluation of changes in mercury and zinc concentrations in Patella coerulea. Bull Environ Contam Toxicol 1987;38:700-6.

Puente X, Villares R, Carral E, Carballeira A. Nacreous shell of Mytilus galloprovincialis as a biomonitor of heavy metal pollution in Galiza (NW Spain). Sci Total Environ 1996;183(3):205-11.

Rainbow PS. Heavy metals in marine invertebrates. In: Furness RW, Rainbow PS, editors. Heavy metals in the marine environment. Boca Raton, FL: CRC Press; 1990. p. 67-79.

Rainbow PS. The significance of accumulated heavy metal concentrations in marine organisms. In: Miskiewicz AG, editor. Assessment of the distribution, impacts, and bioaccumulation of contaminants in aquatic environments. Sydney: Proc Bioacc Workshop: Water Board and Australian Marine Sciences Association; 1992. p. 1-13.

Rainbow PS. The significance of trace metal concentrations in marine invertebrates. In: Dallinger R, Rainbow PS, editors. Ecotoxicology of metals in invertebrates. Boca Raton: Lewis Publ; 1993. p. 3-23.

Rainbow PS. Trace metal accumulation in marine invertebrates: marine biology or marine chemistry? J Mar Biol Assoc UK 1997;77:195-210.

Rainbow PS, Phillips DJH. Cosmopolitan bioindicators of trace metals. Mar Pollut Bull 1993;26(11):593-601.

Ramelow GJ. A study of heavy metals in limpets (Patella sp.) collected along a section of the southeastern Turkish Mediterranean coast. Mar Environ Res 1985;16:243-53.

Richardson CA, Chenery SRN, Cook JM. Assessing the history of trace metal $(\mathrm{Cu}, \mathrm{Zn}, \mathrm{Pb})$ contamination in the North Sea through laser ablation ICP-MS of horse mussel Modiolus modiolus shells. Mar Ecol, Prog Ser 2001;211:157-67.

Runham NW, Thornton PR, Saw DA, Wayte RC. The mineralization and hardness of the radular teeth of the limpet Patella vulgata L. Z Zellforsch 1969;99:608-26.

Segar DA, Collins JD, Riley JP. The distribution of the major and some 
minor elements in marine animals: Part II. Molluscs. J Mar Biol Assoc UK 1971;51:131-6.

Soto M, Kortabitarte M, Marigómez I. Bioavailable heavy metals in estuarine waters as assessed by metal/shell-weight indices in sentinel mussels Mytilus galloprovincialis. Mar Ecol, Prog Ser 1995;125(1-3): $127-31$.

Soto M, Ireland MP, Marigómez I. The contribution of metal/shell-weight index in target-tissues to metal body burden in sentinel marine molluscs: 2. Mytilus galloprovincialis. Sci Total Environ 1997;198(2): $149-60$.

Sturesson U. Cadmium enrichment in shells of Mytilus edulis. Ambio 1978; 7:122-5.

Szefer P, Szefer K. Occurrence of ten metals in Mytilus edulis L. and Cardium glaucum L., from Gdansk Bay. Mar Pollut Bull 1985;16(11): $446-50$.

Szefer P, Szefer K. Metals in molluscs and associated bottom sediments of the southern Baltic. Helgol Meeresunters 1990;44:424-41.

Szefer P, Ikuta K, Kushyiama S, Frelek K, Geldon J. Distribution of trace metals in the Pacific oyster, Crassostrea gigas, and crabs from the east coast of Kyushu Island, Japan. Bull Environ Contam Toxicol 1997;58(1): $108-14$.
Szefer P, Frelek K, Szefer K, Lee Ch-B, Kim B-S, Warzocha J, et al. Distribution and relationships of trace metals in soft tissue, byssus and shells of Mytilus edulis trossulus from the southern Baltic. Environ Pollut 2002;120:423-44.

Waldichuk M. Some biological concerns in heavy metal pollution. In: Vernberg FJ, Vernberg WB, editors. Pollution and physiology of marine organisms. New York: Academic Press; 1974. p. 1-55.

Walsh K, Dunstan RH, Murdoch RN, Conroy BA, Roberts TK, Lake P. Bioaccumulation of pollutants and changes in population parameters in the gastropod mollusc Austrocochlea constricta. Arch Environ Contam Toxicol 1994;26(3):367-76.

Walsh K, Dunstan RH, Murdoch RN. Differential bioaccumulation of heavy metals and organopollutants in the soft tissue and shell of the marine gastropod, Austrocochlea constricta. Arch Environ Contam Toxicol 1995;28(1):35-9.

Watson, D. The shell of Semibalanus(=Balanus) balanoides as a bioindicator of trace metal levels in the marine environment. PhD Thesis, University of Wales; 1993.

Watson D, Foster P, Walker G. Barnacle shells as biomonitoring material. Mar Pollut Bull 1995;31(1-3):111-5. 